\title{
$\underline{\underline{\alpha}}$ INTERNATIONAL RESEARCH JOURNAL OF PHARMACY \\ www.irjponline.com \\ ISSN $2230-8407$ \\ Research Article
}

\section{SYNTHESIS, CHARACTERIZATION AND STUDY OF ANTIMICROBIAL ACTIVITY OF 2,6-DITERTIARY BUTYL-1,4-BENZOQUINONE HYDRAZONES}

\author{
Anees Pangal, Khursheed Ahmed* and Sajid Shaikh \\ Dept. of Chemistry and Post Graduate Centre, Abeda Inamdar Sr. College of Arts, Science and Commerce Camp, \\ University of Pune, Pune, India \\ *Corresponding Author Email: aagpan@gmail.com
}

Article Received on: 10/06/13 Revised on: 01/07/13 Approved for publication: 11/08/13

DOI: 10.7897/2230-8407.04834

IRJP is an official publication of Moksha Publishing House. Website: www.mokshaph.com

(C) All rights reserved.

\section{ABSTRACT}

Four 2,6-di-tert-butyl-1,4-benzoquinone hydrazones have been synthesized viz. A1, A2, A3 and A4. The purity was checked using HPLC. These compounds were characterized by FTIR and $\mathrm{H}^{1}$-NMR and they shows a prominent absorption of $-(\mathrm{C}=\mathrm{N}-)$ in FTIR. It also shows a common peak of oleifinic proton at 6.50 Hz. These hydrazones were tested for their antimicrobial activity against Gram +ve and Gram -ve bacteria. A3 was found to be active at a minimum concentration of $50 \mu \mathrm{g} \cdot \mathrm{mL}^{-1}$ where as $\mathrm{A} 2$ was inactive.

Keyword: Hydrazones, 2,6-Di-tert-butyl-1,4-benzoquinone, antimicrobial activity, Hydrazone derivatives.

\section{INTRODUCTION}

Benzoquinones are the compounds with important biological functions in oxidative phosphorylation and electron transfer processes $^{1}$, bioenergetic transport ${ }^{2,3}$. They possess diverse pharmacological properties such as anti-inflammatory ${ }^{4}$, antimicrobial $^{5,6}$, antiviral activities ${ }^{7}$ and anticancer ${ }^{8-11}$. The compounds are used in the design and synthesis of various heterocyclic drug molecules as potential synthetic building blocks. The importance of research on these compounds in recent years is provided by the discovery of chemo preventive and therapeutic properties observed for a naturally occurring benzoquinone compound, viz. Thymoquinone, which is found in the Black Cumin (Nigella sativa) seed oil ${ }^{12}$. The black cumin seeds are being used as a spice in the Mediterranean region and in Western Asian countries including India. This herb is known by many different names such as 'Kalonji' in India 'Panacea' in Latin, 'Habbah Sawda' in Arabic, or 'Hak Jung Chou' in Chinese. The extracts of this plant have indicated potent antitumor activities without serious toxic effects suggesting that compounds having benzoquinone nucleus may be developed into useful therapeutic agents ${ }^{13}$. Most of the investigations on the biogenesis of benzoquinones have been reported with moulds such as Aspergillus fumigatus and Pencillium patulum $^{14}$. Benzoquinones are the simplest structural quinines which are widely distributed in plants, animals and bacteria. Majority of the fungal benzoquinones are formed by the acetatemalonate pathway yielding ubiquinones having polyprenyl side chains ${ }^{15}$. These compounds are found in most aerobic organisms from bacteria to higher plants and animals and are involved in mitochondrial electron transport chains. The Streptomyces bacteria also produce large number of nitrogen containing heterocyclic quinones ${ }^{16}$. Radio-labelled precursor studies have indicated two biosynthetic routes for the formation of benzoquinone compounds which serve as important toxic defense for many insects and arthropods such as methylbenzoquinone, 2, 3-dimethyl and 2, 5dimethylbenzoquinone. Comparatively less is known about the biogenesis of benzoquinones in higher plants ${ }^{17}$. The methods employed to isolate naturally occurring benzoquinones are common to natural products chemistry and involve sequential extraction with solvents of increasing polarity while the appropriate fractions are purified by column or thin layer or preparative thin layer chromatography. Ultrasonic or critical fluid extractions carried out in recent years offer advantages in terms of avoiding residual solvent levels ${ }^{18}$. Chemically 1, 4benzoquinone is a multi-functional moiety exhibiting properties of a ketone, oxidant and an alkene undergoing addition reactions. It is a simple six-membered, non-aromatic compound which is the oxidised derivative of 1, 4dihydroquinone. It can be easily reduced to 1, 4-benzenediol. Equimolar mixture of 1, 4-benzoquionone and 1, 4benzenediol which is used as a standard electrode material is known as quinhydrone ${ }^{19}$. Several features make it an attractive motif for building supramolecular assemblies which are associated with the quinonoidal structure. Similarly, the quinonoidal carbonyl groups are capable of evolving hydrogen bonded assemblies yielding inclusion compounds $^{20,21}$. The electron deficient benzoquinone system also yields charge transfer complexes very easily ${ }^{22-27}$. The facile redox cycling associated with benzoquinones makes them excellent oxidizing agents ${ }^{28}$. They are known to react with acetic anhydride and sulphuric acid to give triacetate of 1, 3, 4-trihydroxybenzene and the reaction is known as Thiele reaction ${ }^{29}$. They react with large number of primary and secondary aliphatic or aromatic amines yielding mostly disubstituted compounds. The benzoquinones easily undergo nucleophilic addition reactions and serve as an excellent dienophiles in the Diels- Alder reaction. However, single substitution is observed with secondary amines under selected conditions. During such substitutions one or two moles of reduced benzoquinone molecules are also formed as shown in Figure $1^{30}$. Harley-Mason and Laird ${ }^{31}$ have reported on the formation of 1, 2, 3, 4-tetrahydro-1, 4, 5, 8-tetraazaanthracene after reacting 2, 5-dihydroxy-p-benzoquinone with ethylenediamine in presence of air in aqueous media. A similar reaction with 2,3-dimethoxy-p-benzoquinone and ethylenediamine yields 2, 5-bis(2-hydroxyethylamino)-3, 6dichloro-1, 4-benzoquinone which on further heating for several hours gives tetra-aza-anthracene Figure $2^{32}$. Aromatic amines also undergo nucleophilic substitution at 2 and 5 
position of p-benzoquinone. For example, Aseed and Omer have synthesised 2, 5-Diamino-3, 6-dibromo-1, 4benzoquinone by reacting various amines with $2,3,5$, 6tetrabromo-1, 4-benzoquinone Figure 3 which exhibit antibacterial activity against Aspergillus niger and Candida albicans respectively ${ }^{33}$. In present paper we have reported the synthesis and antimicrobial or antibacterial activity of four hydrazones of 2,6-Di-tert-butyl-1,4-benzoquinone. The compounds are tested for their antimicrobial activity against Gram +ve (Staphylococcus aureus) and Gram -ve (Escherichia coli).

\section{MATERIALS AND METHODS}

Solvents for synthesis were reagent grade and dried by standard procedures ${ }^{23}$. The starting materials such as 2,6ditertiary butyl-1,4-benzoquinone, thiosemicarbazide, 4hydroxy benzoic acid hydrazide, 3-hydroxy naphthoic acid hydrazide, Indol 3-acetic hydrazide, were obtained from
Sigma-Aldrich chemicals and acetone, methanol, ethanol and dichloromethane, which were obtained from SRL Chemical Limited, India. All compounds were routinely checked by TLC on silica gel G plates using petroleum ether / ethyl acetate $(7: 3 ; 6: 4 ; 5: 5$ by V/V) as solvent system and the developed plates were visualized by UV light and iodine vapours. The detailed synthesis has been shown in Scheme 1. Melting points of as synthesized compounds were determined with open capillary tube on a VEEGO melting point apparatus. The $\mathrm{H}^{1}$-NMR and Liquid chromatography mass spectra (LCMS) were obtained from NCL, Pune, India and purity was checked by "HPLC-Systronics". IR spectra were recorded by "FT- IR Jasco" spectrometer at the centre. Nutrient broth was used for growth of the organisms. The media was prepared and autoclaved for 15 minutes at $121^{\circ} \mathrm{C}$, $15 \mathrm{lb}$ pressure. The autoclaved media were inoculated with seed culture and incubated at $37^{\circ} \mathrm{C}$ for 24 hours.

Table 1: Antimicrbial Activity Results in Comparison with Standard

\begin{tabular}{|c|c|c|c|c|c|c|}
\hline Compound $\left(\boldsymbol{\mu g} \cdot \mathbf{m L}^{-\mathbf{1}}\right)$ & \multicolumn{3}{|c|}{ Staphylococcus aureus $(\mathbf{G}+)$} & \multicolumn{3}{c|}{ E. coli $(\mathbf{G}-)$} \\
\hline & 50 & 100 & 150 & 50 & 100 & 150 \\
\hline A1 & - & 3 & 5 & 1 & 4 & 5 \\
\hline A2 & - & - & - & - & - & - \\
\hline A3 & 1 & 2 & 4 & 1 & 1 & 2 \\
\hline A4 & - & 1 & 2 & 2 & 2 & 3 \\
\hline DMSO & - & - & - & - & - & - \\
\hline Ciprofloxacin & 5 & 6 & 9 & 6 & 6 & 8 \\
\hline
\end{tabular}<smiles>[R]CCCNC1=CC(=O)C(N[R10])=CC1=O</smiles>

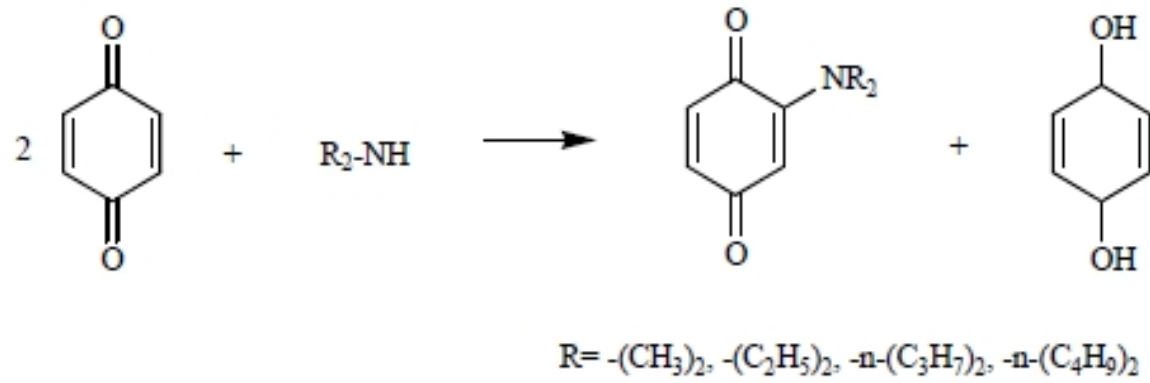

Figure 1: Nucleophilic Substitution Reations of Benzoquinone 


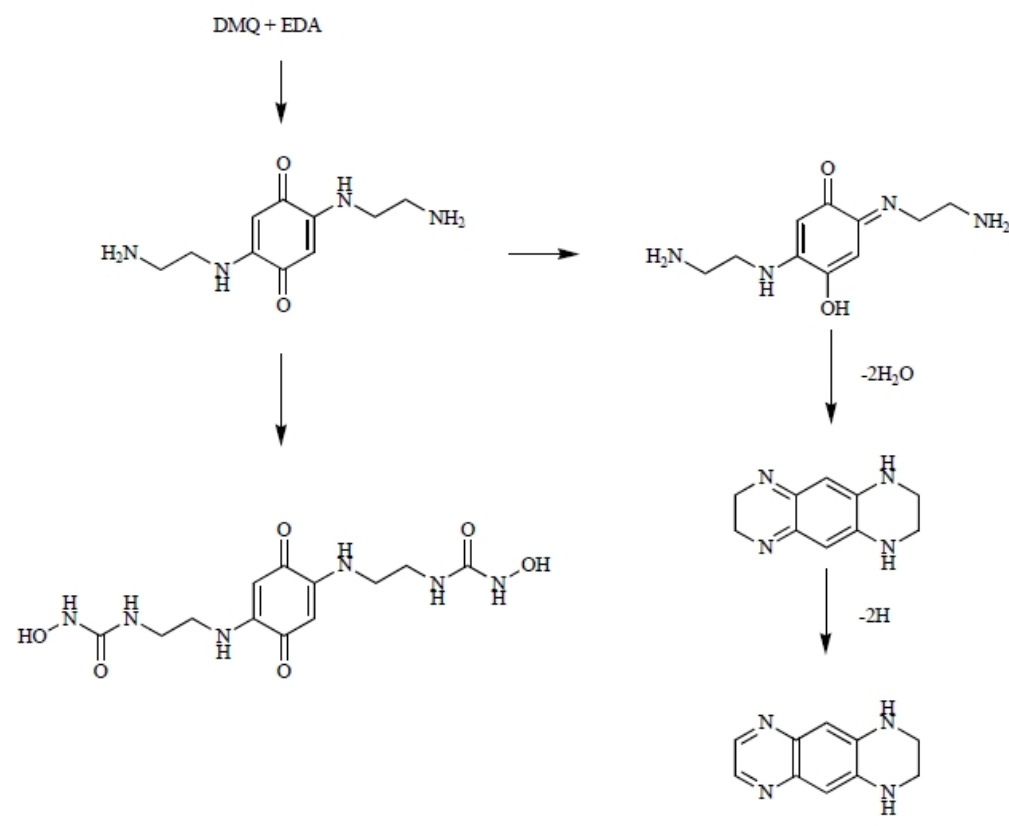

Fig (2). Preparation of tetra-aza-anthracene from reaction of 2,5-dihydroxy-1,4-benzoquinone with ethylene diamine (EDA).<smiles>[R]c1ccc(N)cc1</smiles><smiles>O=C1C(Br)=C(Nc2ccccc2)C(=O)C(Br)=C1Nc1ccccc1</smiles>

$\mathrm{R}=-\mathrm{H},-\mathrm{SO}_{2}-\mathrm{C}_{6} \mathrm{H}_{4}-\mathrm{NH}_{2},-\mathrm{COOH},-\mathrm{SO}_{2} \mathrm{NH}_{2}$, $-\mathrm{NO}_{2},-\mathrm{CH}_{3},-\mathrm{SO}_{2} \mathrm{NH}-\mathrm{C}_{6} \mathrm{H}_{4}-\mathrm{SO}_{2}-\mathrm{NH}_{2}$

Fig (3). Reaction of tetrabromo-substituted 1, 4-benzoquinone with amines.

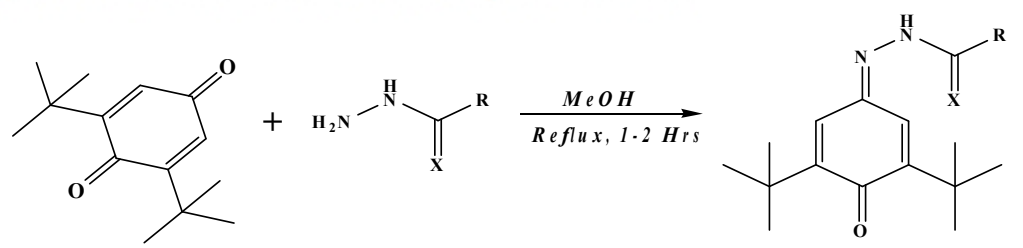

2,6-di-tert-butyl-1,4-benzoquinone Hydrazide

2,6-di-tert-butyl-1,4-benzoquinonehydrazone

Where-

A $1 \quad \mathbf{R}=$<smiles>CCc1c[nH]c2ccccc12</smiles>

$\mathbf{x}=\mathbf{0}$

A 2

$\mathbf{R}=$

$-\mathrm{NH}_{2}$

$\mathbf{X}=\mathbf{S}$

A3

$\mathbf{R}=$

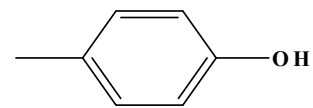

$\mathbf{X}=\mathbf{o}$

A 4

$\mathbf{R}=$<smiles>Cc1cc2ccccc2cc1O</smiles>

$\mathbf{X}=\mathbf{O}$

Scheme 1: General Scheme of Synthesis of Hydrazones 
RESULTS AND DISCUSSIONS

Procedure for the Synthesis of A1: N'-(3,5-di-tert-butyl-4oxocyclohexa-2,5-dienylidene)-2-(1H-indol-2-

yl)acetohydrazide

$200 \mathrm{mg}$ of 2,6-ditertiarybutyl-1,4-benzoquinone and $172 \mathrm{mg}$ Indol-3-acetic acid hydrazide were dissolve it in the $15 \mathrm{ml}$ methanol and refluxed for 2-3 hours with constant stirring. Monitor the reaction by TLC. The reaction mixture was poured in ice to get orange coloured solid. Colour: Orange. Yeild: $69 \%$, M. P.: $198^{\circ} \mathrm{C}$. Purity (HPLC): $99.6 \%$, Mass (LCMS): 391, FTIR $\left(\mathrm{KBr}, \mathrm{cm}^{-1}\right): 3265.86(-\mathrm{NH}), 2958.27$ ($\mathrm{CH}), 1660.41(-\mathrm{C}=\mathrm{O}), 1647.56(-\mathrm{C}=\mathrm{N}), 1057.03(-\mathrm{N}-\mathrm{N}) . \mathrm{H}^{1}-$ NMR $\left(\mathrm{CDCl}_{3}\right)(\delta, \mathrm{ppm}): 1.29\left(\mathrm{~s}, 18 \mathrm{H},-\mathrm{C}\left(\mathrm{CH}_{3}\right)_{3}\right), 3.56(\mathrm{~s}$, $\left.2 \mathrm{H},-\mathrm{CH}_{2}-\right), 6.49(\mathrm{~s}, 2 \mathrm{H}$, oleifinic $\mathrm{H}), 7.24(\mathrm{~s}, 1 \mathrm{H},-\mathrm{NH}), 7.36$ (s, 4H), 6.66 (s, 1H, indolic H), 10.4 (s, 1H, indolic NH).

Procedure for the Synthesis of A2: (1-(3,5-di-tert-butyl-4oxocyclohexa-2,5-dienylidene) thiosemicarbazide

$200 \mathrm{mg}$ of 2,6-ditertiarybutyl-1,4-benzoquinone and 82.72 $\mathrm{mg}$ thiosemicarbazide were dissolve it in the $15 \mathrm{ml}$ methanol and refluxed for 2-3 hours with constant stirring. Monitor the reaction by TLC. The reaction mixture was poured in ice to get yellow coloured solid. Colour: Yellow. Yeild: $85 \%$, M. P.: $66^{\circ} \mathrm{C}$. Purity (HPLC): $98.7 \%$, Mass (LCMS): 293, FTIR $\left(\mathrm{KBr}, \mathrm{cm}^{-1}\right): 3385.42(-\mathrm{NH}), 2963.09(-\mathrm{CH}), 1671.02(-\mathrm{C}=\mathrm{O})$, $1525.42(-\mathrm{C}=\mathrm{N}), 1139.72(-\mathrm{N}-\mathrm{N}) . \mathrm{H}^{1}-\mathrm{NMR}(\mathrm{CDCl})(\delta$, ppm, ): 1.28 (s, 18H, -C(CH3)3), 2.5 (s, 2H, -NH2), 6.50 (s, $2 \mathrm{H}$, oleifinic $\mathrm{H}), 7.24$ (s, $1 \mathrm{H},-\mathrm{NH})$.

Procedure for the Synthesis of A3: N'-(3,5-di-tert-butyl-4oxocyclohexa-2,5-dienylidene)-4-hydroxybenzohydrazide $200 \mathrm{mg}$ of 2,6-ditertiarybutyl-1,4-benzoquinone and $138 \mathrm{mg}$ 4-hydroxy benzoic acid hydrazide were dissolve it in the 15 $\mathrm{ml}$ methanol and refluxed for 2-3 hours with constant stirring. Monitor the reaction by TLC. The reaction mixture was poured in ice to get yellow coloured solid. Colour: Yellow. Yeild: $89 \%$, M. P.: $164^{\circ} \mathrm{C}$. Purity (HPLC): $99.8 \%$, Mass (LCMS): 354. FTIR $\left(\mathrm{KBr}, \mathrm{cm}^{-1}\right): 3370(-\mathrm{NH}), 3026.20(-$ $\mathrm{OH}), 2958.27(-\mathrm{CH}-), 1618.95(-\mathrm{C}=\mathrm{O}), 1551.45(-\mathrm{C}=\mathrm{N})$, $1225.21(-\mathrm{N}-\mathrm{N}) . \mathrm{H}^{1}-\mathrm{NMR}\left(\mathrm{CDCl}_{3}\right)(\delta, \mathrm{ppm}):, 1.28(\mathrm{~s}, 18 \mathrm{H},-$ $\left.\mathrm{C}\left(\mathrm{CH}_{3}\right)_{3}\right), 3.56\left(\mathrm{~s}, 2 \mathrm{H},-\mathrm{CH}_{2}-\right), 6.50$ (s, $2 \mathrm{H}$, oleifinic $\left.\mathrm{H}\right), 7.24$ (s, $1 \mathrm{H},-\mathrm{NH}), 7.84(\mathrm{dd}, \mathrm{J}=8 \mathrm{~Hz}, 2 \mathrm{H}), 7.68(\mathrm{dd}, \mathrm{J}=8 \mathrm{~Hz}$, $2 \mathrm{H}), 9.75(\mathrm{~s}, 1 \mathrm{H}$, exchangeable $-\mathrm{OH})$.

Procedure for the Synthesis of A4: N'-(3,5-di-tert-butyl-4oxocyclohexa-2,5-dienylidene)-3-hydroxynaphthalene-2carbohydrazide

$200 \mathrm{mg}$ of 2,6-ditertiarybutyl-1,4-benzoquinone and 183.63 mg 3-hydroxy 2-naphthoic hydrazide were dissolve it in the $15 \mathrm{ml}$ methanol and refluxed for 2-3 hours with constant stirring. Monitor the reaction by TLC. The reaction mixture was poured in ice to get yellow coloured solid. Colour: Yellow. Yeild: $85 \%$, M. P.: $202^{\circ} \mathrm{C}$. Purity (HPLC): $99.6 \%$, Mass (LCMS): 404. FTIR (KBr, cm $\left.{ }^{-1}\right): 3426.89(-\mathrm{NH})$, $3291.89(-\mathrm{OH}), 2968.87(-\mathrm{CH}), 1589.70(-\mathrm{C}=\mathrm{O}), 1504.20 \quad(-$ $\mathrm{C}=\mathrm{N}), 1057.03(-\mathrm{N}-\mathrm{N}) . \mathrm{H}^{1}-\mathrm{NMR}\left(\mathrm{CDCl}_{3}\right)(\delta, \mathrm{ppm}):, 1.28(\mathrm{~s}$, $\left.18 \mathrm{H},-\mathrm{C}\left(\mathrm{CH}_{3}\right)_{3}\right), 6.50(\mathrm{~s}, 2 \mathrm{H}$, oleifinic $\mathrm{H}), 7.24(\mathrm{~s}, 1 \mathrm{H},-\mathrm{NH})$, 7.66 (m, 6H, naphthoic $\mathrm{Hs}), 9.73(\mathrm{~s}, 1 \mathrm{H}$, exchangeable $-\mathrm{OH})$.

\section{Antimicrobial Activity}

The anti-microbial results showed that some of the compounds were active against both Gram-positive Staphylococcus aureus and Gram-negative Escherichia coli bacteria. Among the tested compounds the compounds A1, A3 and A4 showed good antibacterial activity against the test organisms. The compound A2 had no anti-bacterial activity against. Maximum antibacterial activity was shown by compounds containing the heterocyclic rings in the structure. On the other hand, compared to the standard antibacterial drugs namely, Ciprofloxacin was showed moderate activity against test organisms. The obtained results of antibacterial activity have been summarized in Table 1 .

\section{CONCLUSION}

Out of four hydrazones synthesized only three shows effective antibacterial activity. A1 is more active than A3 and A4 where as A2 is non-active. All the three hydrazones are moderately active when compared with ciprofloxacin. The Minimum Inhibitory Concentration (MIC) of A1 is 100 $\mu \mathrm{g} \cdot \mathrm{mL}^{-1}$ for Gram +ve and $50 \mu \mathrm{g} \cdot \mathrm{mL}^{-1-}$ for Gram -ve bacteria; whereas the MICs for $\mathrm{A} 3$ and $\mathrm{A} 4$ are 50 and 100 $\mu \mathrm{g} \cdot \mathrm{mL}^{-1}$ respectively for Gram +ve and $50 \mu \mathrm{g} \cdot \mathrm{mL}^{-1}$ each for Gram -ve bacteria. The shown activity can be accounted for the presence of either a heterocyclic or an aromatic moiety in the respective hydrazide. As the synthesized hydrazones are biological active, study of their anticancer activity is of our further interest.

\section{ACKNOWLEDGMENT}

The authors are grateful to the principal, Abeda Inamdar Senior College, Pune, India for extending the laboratory facilities. The authors are also like to acknowledge encouragement and assistance received from the authorities of Abeda Inamdar Senior College, Pune, India.

\section{REFERENCES}

1. Arntzen CJ, Pakrasi HB. Photosystem II reaction center: Polypeptide subunits and functional cofactors. In: Encyclopedia of Plant Physiology. New series, Staehelin; L. Al; Arntzen, C.J.; Eds.; Springer-Verlag: Berlin 1986; 19: 457-467.

2. Pink JJ, Planchon SM, Tagliarino C, Varnes ME, Siegel D, Boothman DA. NAD $(\mathrm{P}) \mathrm{H}$ : Quinone oxidoreductase activity is the principal determinant of $\pi$-lapachone cytotoxicity. J. Biol. Chem 2000; 275: 54165424. http://dx.doi.org/10.1074/jbc.275.8.5416 PMid:10681517

3. Ross D, Kepa JK, Winski SL, Beall HD, Anwar A, Siegel D. NAD(P)H: quinone oxidoreductase 1 (NQO1): chemoprotection, bioactivation, gene regulation and genetic polymorphisms. Chem. Biol. Interact 2000; 129 : 77-97. http://dx.doi.org/10.1016/S0009-2797(00)00199-X

4. Sagnou M, Strongilos A, Hadjipavlou Litina D, Couladouros EA. Synthesis of Novel Benzoquinones with Anti-Inflammatory Activity. Lett. Drug Des. Discov 2009; 6: 172-177. http://dx.doi.org/ 10.2174/157018009787847792

5. Yezerski A, Ciccone C, Rozitski J, Volingavage B. The effects of a naturally produced benzoquinone on microbes common to flour. J. Chem. Ecol 2007; 33: 1217-1225. http://dx.doi.org/10.1007/s10886-0079293-2 PMid: 17473960

6. Awino OS, Kiprono PC, Keronei KP, Kaberia F, Obala AA. Antimicrobial activity of 2,5-dihydroxy-3-methyl-1,4-benzoquinone from Embelia schimperi. Z Naturforsch. C 2008; 63: 47-50. PMid: 18386487

7. Bogdanova NS, Pershin GN, Nikolaeva IS, Grinev AN, Shvedov VI. Antiviral activity of p-benzoquinone and hydroquinone derivatives. Farmakol. Toksikol 1970; 33: 488-496. PMid:5525967

8. Lindsey RH, Jr Bromberg KD, Felix CA, Osheroff N. 1,4-Benzoquinone is a topoisomerase II poison. Biochemistry 2004; 43: 7563-7574. http://dx.doi.org/10.1021/bi049756r PMid: 15182198

9. Lee CS. Excision repair of 2, 5-diaziridinyl-1,4-benzoquinone (DZQ)DNA adduct by bacterial and mammalian 3-methyladenine-DNA glycosylases. Mol. Cell 2000; 10: 723-727. http://dx.doi.org/10.1007 /s100590000035

10. Beall HD, Murphy AM, Siegel D, Hargreaves RH, Butler J, Ross D. Nicotinamide adenine dinucleotide (phosphate): quinine oxidoreductase (DT-diaphorase) as a target for bio reductive antitumor quinones: quinone cytotoxicity and selectivity in human lung and breast cancer cell lines. Mol. Pharmacol 1995; 48: 499-504. PMid:756563

11. Winski SL, Hargreaves RH, Butler J, Ross D. A new screening system for $\mathrm{NAD}(\mathrm{P}) \mathrm{H}$ :quinone oxidoreductase (NQO1)-directed antitumor quinones: identification of a new aziridinylbenzoquinone, $\mathrm{RH} 1$, as a NQO1-directed antitumor agent. Clin. Cancer Res 1998; 4: 3083-3088. PMid:9865924 
12. Aggarwal BB, Kunnumakkara AB, Harikumar KB, Tharakan ST, Sung B, Anand P. Potential of Spice-Derived Phytochemicals for Cancer Prevention. Planta Med 2008; 74: 1560-1569. http://dx. doi.org/10.1055/s-2008-1074578 PMid: 18612945

13. Padhye S, Banerjee S, Ahmad A, Mohammad R, Sarkar FH. From here to eternity - the secret of Pharaohs: Therapeutic potential of black cumin seeds and beyond. Cancer Ther 2008; 6: 495-510. PMid:19018291 PMCid:PMC2583426

14. Packter NM. Studies on the biosynthesis of quinones in fungi. Incorporation of 6-methylsalicylic acid into fumigatin and related compounds in Aspergillus fumigatus I.M.I. 89353, Biochem J 1965; 97: 321-332. PMid:16749133 PMCid:PMC1264643

15. Thomson RH. Naturally Occurring Quinones, $2^{\text {nd }}$ ed. Academic Press: London; 1971.

16. Mikami Y, Takahashi K, Yazawa K, Arai T, Namikoshi M, Iwasaki S, Okuda S. Biosynthetic studies on Safaramycin A: Quinone antitumor antibiotic produced by Streptomyces lavendulae. J. Biol.Chem 1985; 260: 344-348. PMid:3880741

17. Morton RA. Biochemistry of Quinones, Academic Press: New York; 1965.

18. Patel IC, Skauen DM. Ultrasonic extraction of Cassia acutifolia. J. Pharm. Sci 1969; 58: 1135-1139. http://dx.doi.org/10.1002 /jps.2600580922 PMid:5346081

19. Scholz F, Düsse H, Meyer B. A new pH-sensor based on quinhydrone. Fresenius' J. Anal. Chem 1993; 347: 458-459.

20. Hashimoto M, Takagia H, Yamamuraa K. Three dimensional supramolecules of triptycene-quinone and its 6,7-dimethyl derivative formed by weak intermolecular $\pi-\pi$ interactions and $\mathrm{C}-\mathrm{H} \cdots \mathrm{O}$ hydrogen bonds. Tetrahedron. Lett 1999; 40: 6037-6040. http://dx.doi.org /10.1016/S0040-4039(99)01196-X

21. Berkovitch Yellin Z, Leiserowitz L. The role played by $\mathrm{C}-\mathrm{H} \cdots \mathrm{O}$ and C$\mathrm{H} \cdots \mathrm{N}$ interactions in determining molecular packing and conformation. Acta Crystallogr 1984; B40: 159-165.

22. Laskowski DE. Influence of structural features on formation of solid charge-transfer complexes of quinones with carcinogenic and related non-carcinogenic electron donors. Cancer Res 1967; 27: 903-911. PMid:6025254

23. Inaba K, Takahashi YH, Ito K, Hayashi S. Critical role of a thiolatequinone charge transfer complex and its adduct form in denovo disulfide bond generation by DsbB. Proc. Natl. Acad. Sci.USA 2006; 103: $287-$ 292. http://dx.doi.org/10.1073/pnas.0507570103 PMid:16384917 PMCid:PMC1323469
24. Bangal PR. Hydrogen-bonding and protonation effects on the formation of charge transfer complex between para-benzoquinone and 2,6dimethoxy phenol. Chem. Phys. Lett 2005; 401: 200-204. http://dx. doi.org/10.1016/j.cplett.2004.11.061

25. Regeimbal J, Gleiter S, Trumpower BL, Yu CA, Diwakar M, Ballou DP, Bardwell JCA. Disulfide bond formation involves a quinhydrone-type charge-transfer complex. Proc. Natl. Acad. Sci. USA 2003; 100: 1377913784. http://dx.doi.org/10.1073/pnas.1935988100 PMid:14612576 PMCid:PMC283498

26. Fedyanin IV, Lyssenko KA, Vorontsova NV, Rozenberg VI, Antipin MY. Trans annular interaction in 4,7-[2.2] paracyclophane quinone. Mendleev Commun 2003; 13: 15-16. http://dx.doi.org/ 10.1070/MC2003v013n01 ABEH001693

27. Sugiyama H, Kamogawa H. Studies on polymers containing functional groups. III. Charge transfer interaction between quinone and aza polymers. J. Polym. Sci. Part A-1: Polym. Chem 2003; 4: 2281-2288.

28. Uliana MP, Vieira YW, Donatoni MC, Corrêa AG, Brocksom U, Brocksom TJ. Oxidation of Mono-Phenols to para-Benzoquinones: a Comparative Study. J. Braz. Chem. Soc 2008; 19: 1484-1489. http://dx.doi.org/10.1590/S0103-50532008000800007

29. Thiele J. Thiele Reaction: Formation of triacetoxy aromatic compounds. Ber 1898; 31: 1247-1249.

30. Hikosaka A. The reaction of aliphatic amines with p-benzoquinone, the effect of the alkyl group of amines on the reaction. Bull. Chem. Soc. Jpn 1970; 43: 3928-3929. http://dx.doi.org/10.1246/bcsj.43.3928

31. Harley Mason and Laird AH. Isolation and structure of the fluorescent substances formed in the oxidative reaction of adrenaline and noradrenaline with ethylenediamine. Tetrahedron 1959; 7: 70-76. http://dx.doi.org/10.1016/0040-4020(59)80053-3

32. Asahara $T$, Seno $M$, Teshirogi $T$. Reaction of p-benzoquinone derivatives with ethylenediamine. Bull. Chem. Soc. Jpn 1971; 44: 16871689. http://dx.doi.org/10.1246/bcsj.44.1687

33. Saeed AEM and Omer NMA. Synthesis of some 2,5- diamino-3,6dibromo -1,4-Benzoquinones. Afr. J. Pure. Appl. Chem 2009; 3: 275280.

\section{Cite this article as:}

Anees Pangal, Khursheed Ahmed and Sajid Shaikh. Synthesis, characterization and study of antimicrobial activity of 2,6-ditertiary butyl1,4-benzoquinone hydrazones. Int. Res. J. Pharm. 2013; 4(8):172-176 http://dx.doi.org/10.7897/2230-8407.04834 